\title{
The Theme of "Progress" in Australian and Chinese Cultures
}

\author{
Chunyan Zhang ${ }^{1}$ \\ ${ }^{1}$ Chinese Language \& Culture College, Beijing Normal University, Beijing, China \\ Correspondence: Chunyan Zhang, Chinese Language \& Culture College, Beijing Normal University, 19 \\ Xinjiekouwai Street, Haidian District, 100875, Beijing, China. E-mail: diana0825cn@163.com
}

Received: March 22, 2020

Accepted: April 3, 2020

Online Published: April 8, 2020

doi:10.5539/ach.v12n1p35

URL: https://doi.org/10.5539/ach.v12n1p35

\begin{abstract}
This paper discusses the theme of "progress" in Australian and Chinese cultures in the period of 1920s and 1930s. During this period, both cultures had an outpouring of patriotic and sentimental feelings. In this social context, both cultures constructed a theme of "progress" - the transformation of natural environment with human power, or the active participation in social life, for the purpose of "civilization", a concept closely connected with the idea of social engagement, transformation and modernization. In Australia, this ideology was a continuation of the old idea of transforming "untamed" nature and bringing material progress through human labour; in China, it was a new theme which betrayed the old "reclusive" spirit. In Australia, it is represented most clearly in film, in China, it is represented in both film and painting.
\end{abstract}

Keywords: Progress, Civilization, Participation, Construction

\section{Introduction}

"Progress" is a recurring theme in both Australian and Chinese cultures in the period of 1920s and early 1930s. "Progress" in this paper is a term relating the relationship between nature and human civilization. In this relationship, "progress" on the one hand implies the human civilization of nature through labour, machinery and technology, and on the other hand, implies human participation in changing and improving society.

During the period of the 1920s and early 1930s, both Australian and Chinese cultures were coming to terms with modernity. In this transition from the tradition to the modern, in the context of the national sentiments, both Australian and Chinese cultures represented a theme of progress. In Australia this was a continuation of the longestablished view of human appropriation and control of nature, and the desire of white Australians to "belong" to the new land by appropriating it. This was explicit in some Australian films which showed the settler working the land, transforming nature and bringing civilization as the theme. In Chinese film this theme was clearly represented both in film and painting, therefore I will discuss both film and painting. Film and painting are totally different genres of art, but my emphasis is on the ideology embodied in the works, not art itself.

With regard to the length of the paper, not all films or paintings of this period will be discussed, and not all selected films or paintings are given fully discussion. Some are illustrated in detail and others are just explained in several sentences. As the emphasis of this paper is the analysis of social ideology, the issues of technique, style and medium of films and paintings will not be focused. The discussion of specific representations will be combined with a more general exploration of the ideology and social context that fostered those representations.

\section{The Theme of "Progress" in Australian Film}

In Australian culture this theme was most clearly represented in films. Let me take On Our Selection (1920) as an example. On Our Selection was directed by Raymond Longford (1878-1959). It tells of the Rudd family's adjustment to bush life. The Rudd Family was the archetypal bush family, struggling to make a living by hard labour. The director Langford portrayed the hardships of bush life and emphasized this in scenes of the family at work: felling trees, building their hut, clearing the ground, ploughing, harvesting, pulling the ripened corn and shelling the corn with their hands (Figure 1). The captions to the film, such as "the whole family working like bullocks", and "they delved and toiled in loneliness through the years", enhance the impression of hardship. But even more emphasis is given to the fact that human beings were transforming the land and bringing "progress" to it: in eighteen months, the selection is shown to have developed from a shabby hut with only a single room to a four-room slab hut, a log store-room, a stockyard and eight acres of land under corn. The drought was over, replaced by abundant rain which made the grass lush and the pastures fertile. All this was seen as the reward for 
the family's toil, achieved through the strength of their efforts to turn the wilderness into a humanized and civilized land.

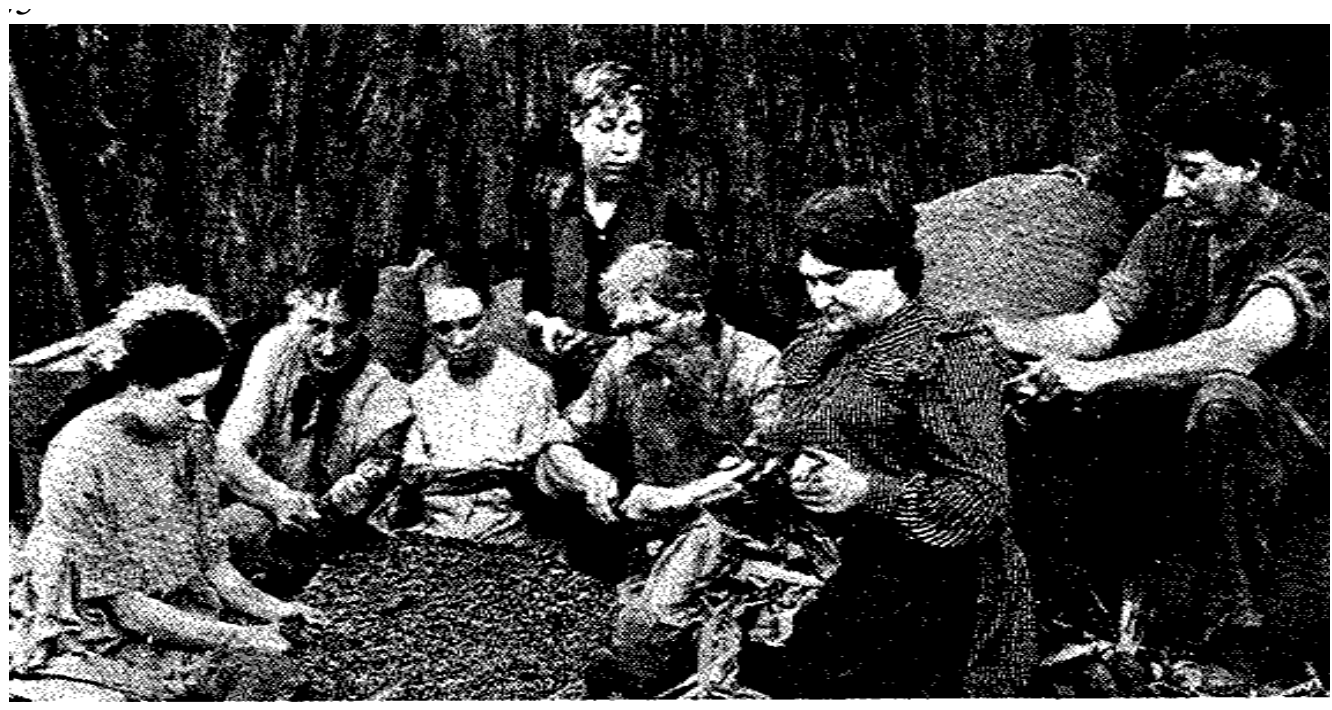

Figure 1. On Our Selection (1920). Rudd's family pulling the ripened corn and shelling the corn with their hands

This film, like most other films of this period (e.g. The Breaking of the Drought (1920) by Franklyn Barrett (18731964)), constructed a myth of final fulfillment achieved through productive human work, transforming the wild bush, the cracked earth and the starving cattle and sheep into a scene of overflowing water casks, rich pastures and fat animals in a "sun-kissed" land (Figure 2). Tulloch argues that in this particular discourse both man's moral and his physical labour soften the extremes of Australian nature, replacing an opposition between man and nature with a bountiful communion (Tulloch, 1981, p. 346). Yet although there is this bountiful communion, the relationship between man and nature is based on the transformation of the wildness of nature through the civilizing agency of humanity.

This sort of representation shows that during this period, the core value of the 19th century in Australia "improvement-progress-settlement" - was still influential (Tulloch, 1981, p. 356). In the 1920s Australian nationalism was influenced by a conservative national tradition which justified the idea of progress. Labour on the land was considered as both the mark of progress and the essence of being Australian, represented by man's transformation of the wilderness into farms and prosperous homes. It was also a justification for those who advocated the construction of a "new nationhood and identity, forged out of the imputed distinction between the 'eager eyes and greedy cosmopolitanism' of the Old World, and the pioneer life on the frontier" (Tulloch, 1981, p. 348). In this "new nationhood and identity", nature was constructed as a "wasteland" waiting to be improved and exploited by human civilization.

This view of labour on the land also underpinned the traditional ideological view that the land belongs to those who work it. This was the ideal of John Locke's belief that property rights should depend on the labour a man put into the land. In On Our Selection, the idea of possession was expressed by such captions as "Pioneers of Australia strove through the silences of Bush-lands and made them ours". It also justified the deep-rooted ideology of dispossession of the Aborigines. This was manifested by such definitive and emblematic lines from the film The Romance of Runnibede (1928) as: "I have cleared every foot of this land and I'm not letting a few blacks drive me away". In this narrative, European pastoralism and agriculture is shown as the means of transforming the landscape from native grasslands to pasture and agricultural plots. Russel Ward expresses a similar opinion, although he discusses it in the wider context of the expansion of industrial civilization. He argues that this was an obvious selfjustification for the exploitative evils of an expanding imperialism, which claimed that its wealth came not from persecuting the natives and taking their land, but from the labour of pioneers (Ward, 1966). Although in reality black men and women were a part of the pastoral workforce, in this cultural construction, they were all absent. By avoiding acknowledgement of Aboriginal representation, the culture makers constructed the idea of an Australia whose progress was solely the result of white intervention. 
This view of labour or progress, using a narrative centred on squatters and selectors, differed from the traditional "progress" theme, which was seen through the legend of the egalitarian bushman. Alomes and Jones have also noted this, and argue that in the inter-war years, this theme stressed values which focused on the settler as squatter and selector rather than on the tradition of the egalitarian bushman as the shearer or drover (Alomes \& Jones, 1991, pp. 232-3). The squatters' legend was one in which the expansion of technology, finance, and patriarchal civilization encouraged the transformation of wilderness; while the selectors' legend was one of privatized farm civilization in which a piece of land, a home and working family became the key icons (as shown in On Our Selection). Different social groups and classes placed emphasis on different aspects of the theme. But they had one thing in common: transforming a "wasteland" into a pastoral paradise through labour. Whether in the ideas of labour and the survival of the fittest, or in the belief of civilizing the land by science, technology, settlement and individual self-improvement, nature was represented as something which was to be transformed for the purpose of "progress".
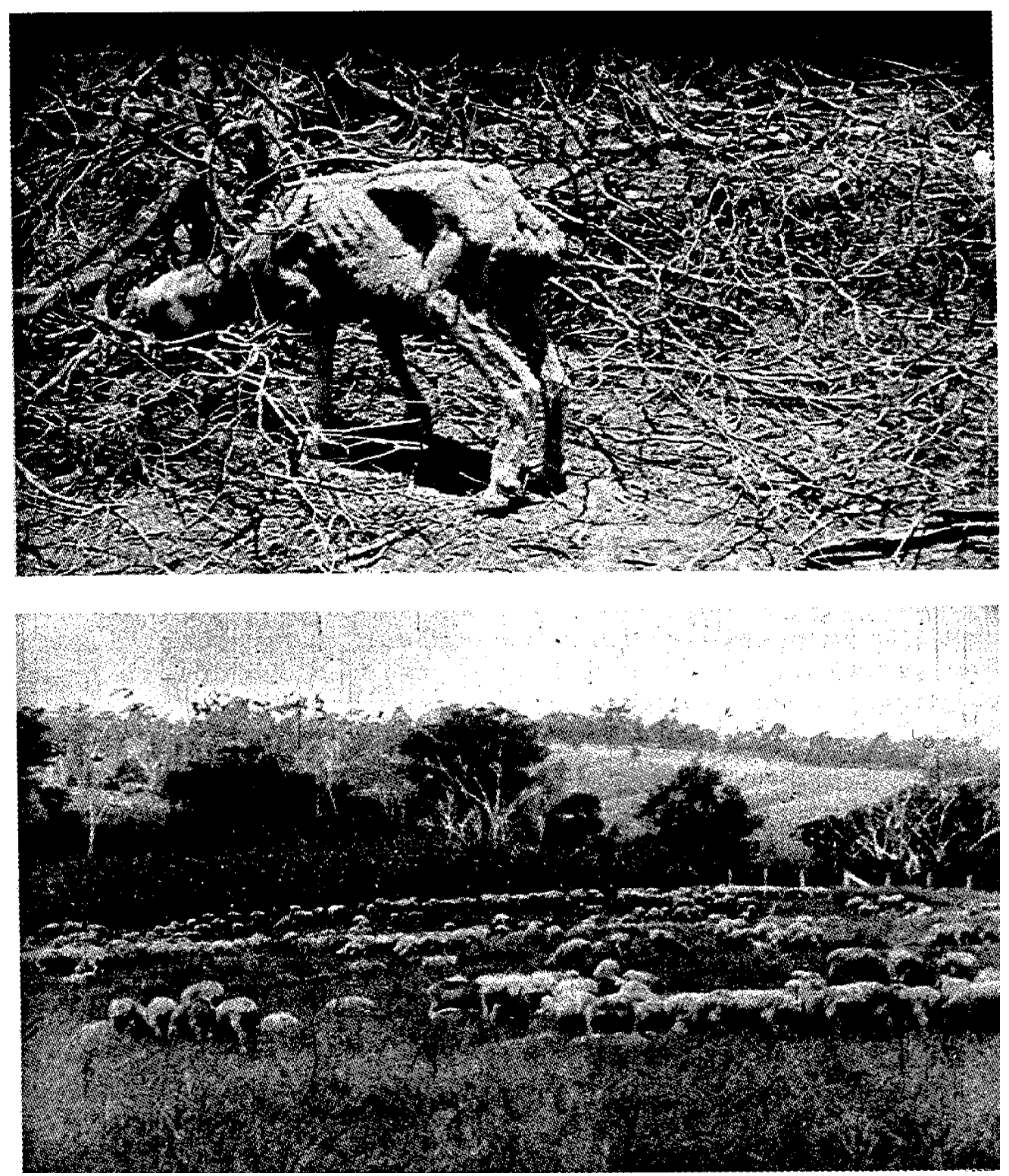

Figure 2. The Breaking of the Drought (1920). From lack to plentitude

This idea during the 1920s was supported by the ideal of "Australia Unlimited" which had the intention of providing "A Million Farms for a Million Farmers" (Alomes \& Jones, 1991, p. 182). Some Australians thought 
that their land could support 100 to 200 million people, and would be increasingly prosperous (Radi, 1974, p. 358). The Hughes government placed great importance on increased population through its immigration and settlement programs. The land and the new settlers were considered to be the basis of this expansion. The government resumed the task of ambitious development, and encouraged closer settlement, and succeeded in making the land more productive (Radi, 1974, p. 358). It also advocated films showing Australia engulfed by a rising tide of prosperity and promoting the idea of "what a great country Australia really is, what can be done with its lands, and how it can be transformed from a wilderness into smiling farms, and prosperous homes" (Tulloch, 1981, pp. 139140). As a result, the ideology and self-image of the 1920 s was one of material growth, explicitly represented in certain films.

In these films, characteristic and impressive shots show a station in a wilderness, a few (or a lone) tree(s), a solitary horse(wo)man and a multitude of sheep, rough tracks, and burning white roofs, which symbolize wealth, human cultivation and control (Figure 3). This can be seen in A Girl of the Bush (1921), in The Hayseeds (1933) and in The Squatter's Daughter (1933). As Tulloch argues, the cultural icons support this comforting notion of purpose and control. The theme of human dominance and control is clearly demonstrated by the competent pioneer on the edge of civilization. This is the mark of progress (Tulloch, 1981, pp. 139-140). This "progress" and "control" are achieved by the victory of human culture over untamed nature. For example, in The Squatter's Daughter, the opening shots show the "achievements" of one and a half centuries of white European settlement in the Monaro in New South Wales. The large flock of sheep, "surely the largest ever assembled anywhere in the world in front of a camera", is proudly paraded before the eyes of the viewer (Hoorn, 2007, p. 69). Produced for international audiences, the film shows the basis for the creation of the wealth which supported the European development of Australia. The image was embedded within the self-consciousness of a national "culture" (Note 1) (Hall, 1977, p. 78).

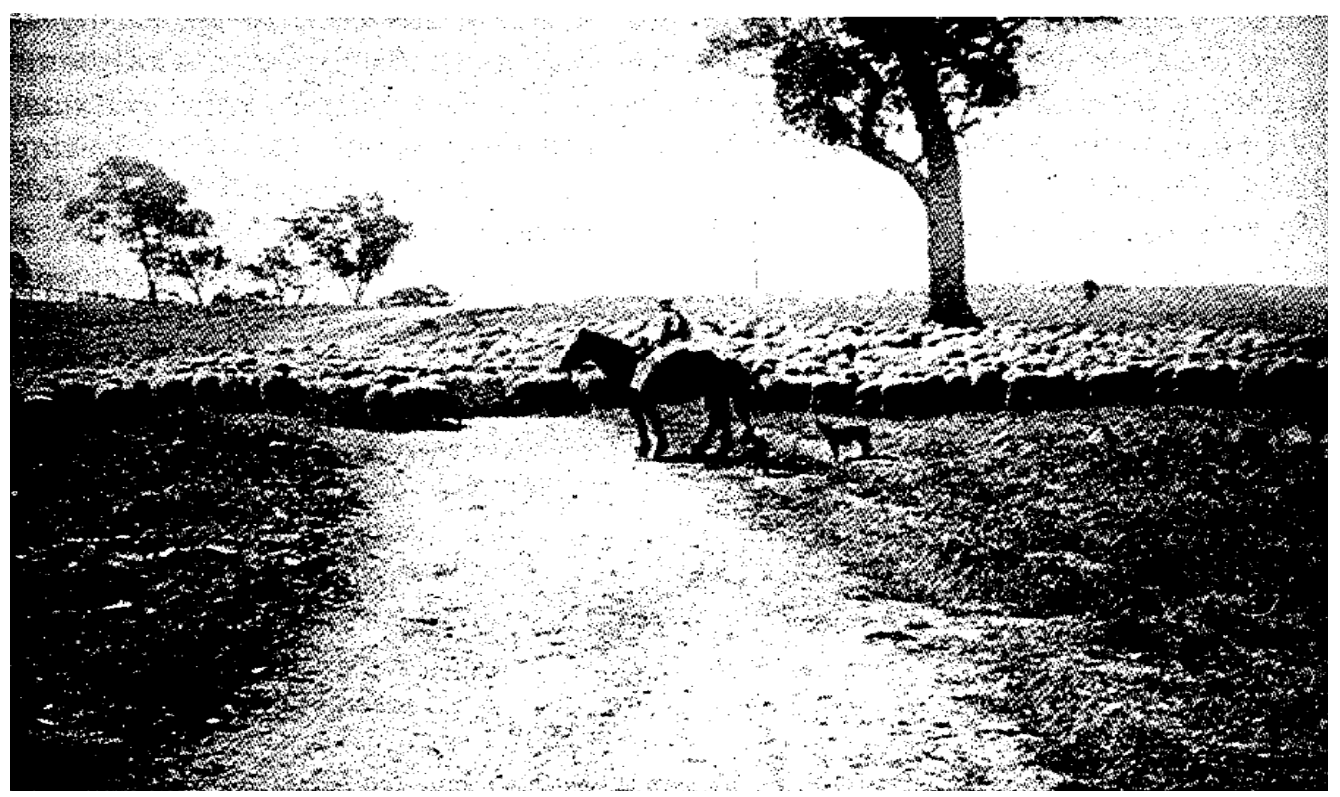

Figure 3. A Girl of the Bush (1921). A few trees, a solitary horseman and a multitude of sheep, rough tracks, and burning white roofs, symbolizing wealth, human cultivation and control

A frequently appearing image in Australian film during this period is a solitary rider sitting comfortably on a stationary horse, watching a crowd of sheep. The sheep cluster together around a single tree. This image shows human civilization and progress. Tulloch argues that the image implies that the Australian "vastness" and pioneering "unknown" are caught up and controlled by the vertical of the tree and the horizontal of sheep and rider, one dynamic connoting "nature", the other "culture". "Yet the tree signifies "culture' too, since it visually extends the vertical dominance of the man. It is also, in a sense, his alibi of power. It is because he is in control of nature that he is, in the Australian cultural domain, a man. Further, the tree has been extracted from the nature behind it on behalf of culture... On the vertical plane the sheep are dominated by the tree, but on the horizontal plane by the rider. They are in nature, but of culture" (Tulloch, 1982, p. 11). His interpretation of the tree as the symbol of 
"culture" and as the "alibi" of the rider's power is much too forced. The fact that the tree has been extracted from its landscape and is visually impressive is not a plausible reason for seeing it as representing "culture". But his opinion is convincing in that this image symbolizes the fact that "culture" controls and dominates "nature", and suggests that the horse(wo)man becomes a real Australian (wo)man in the cultural domain only after he / she is shown to have been successful in controlling nature. In this image, the abundant sheep are a sign of civilized domestication for the use of humans, and more specifically, a sign of the labour undertaken by the horse(wo)man. The rider, sitting comfortably on the horse and watching a crowd of sheep, signifies a pause in the drive to master the land and make it produce wealth. This image is a visual expression of this description of the popularity of paintings on the theme of pioneers, displayed in the Melbourne's Centennial International Exhibition in 1888: “...The unknown wilderness has been made to produce coal and gold, wool and wine...Out of the barren earth there has come wealth, out of the handful of settlers a great people" (Astbury, 1985, p. 130). This image links the legacy of the nation's pioneering image (as the provider of progress, prosperity and civilization out of a "wilderness") in the past to the abundance of the present, to the creation of this material achievement (Figure 4).

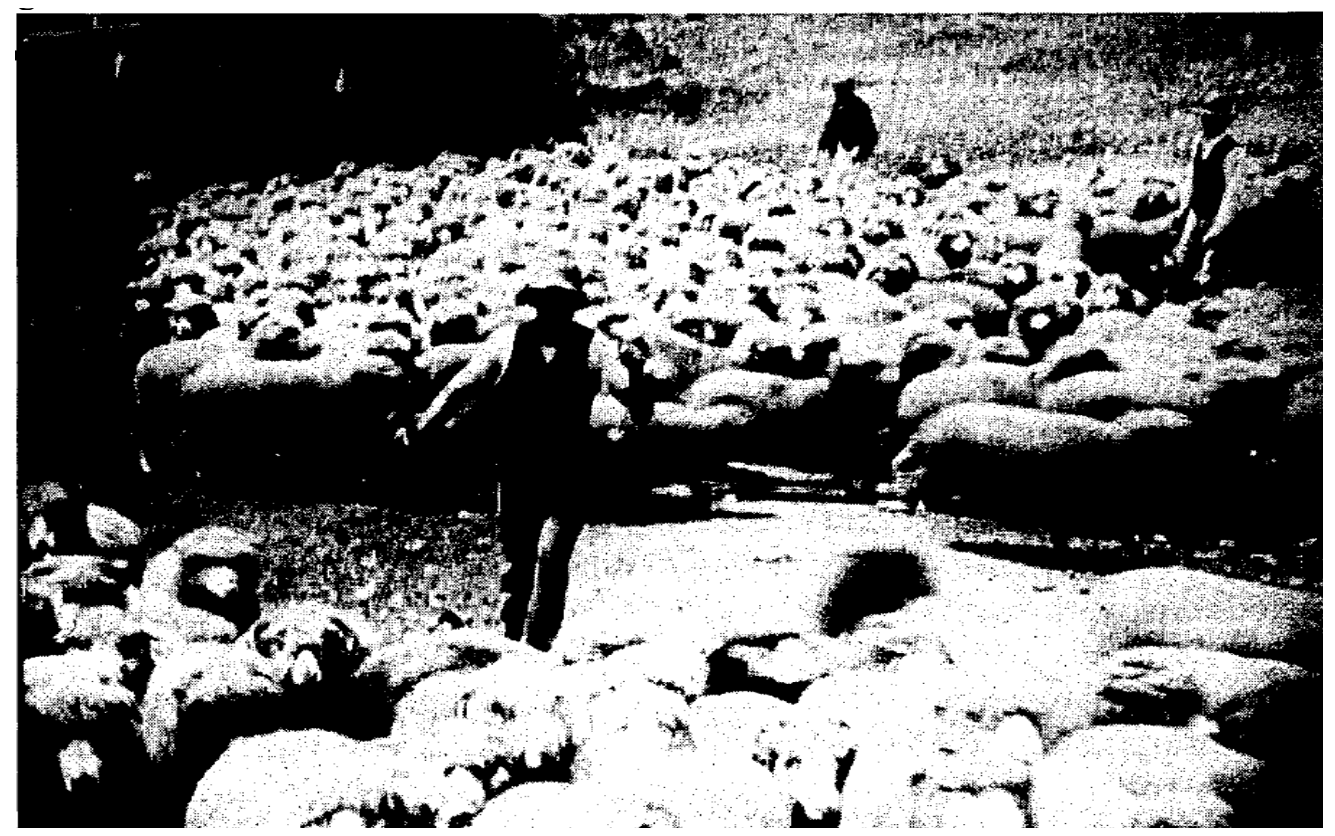

Figure 4. A Girl of the Bush (1921). Abundant sheep: a sign of civilized domestication and "progress"

\section{The Theme of "Progress" in Chinese Film and Painting}

Just as the theme of "progress" had developed in Australia during this period, a similar theme was also under construction in Chinese culture, especially in film and painting. This theme was also catalyzed and strengthened by the intense nationalistic feelings which came out of a sense of national crisis, the result of domestic wars and foreign (Japanese) aggression. But the notion of "progress" in Chinese culture has broader meanings than it has in Australian culture. Besides the transformation of "wilderness" into fertile farming land, and scientific and technological development, it also has the meaning of "actively participating in social life", as suggested by the radical leftist Chen Duxiu's slogans: "Go forward, do not retire" (Note 2) (Lu, 1995, p. 57). Actually during this period, the Chinese sense of "progress" was a concept closely connected with the idea of scientific, social engagement, transformation and modernization. The modern art theorist Mei Mosheng argues that the 1920s and 1930s were a period of Westernization, with emphasis on upholding science, and pursuing material wealth (Mei, 2005, p. 99). Although he does not explicitly link these three characteristics (westernization, upholding science, and the pursuit of material wealth) with the idea of "progress", they are always categorized together as broadly connoting the idea of "progress". Since the Western term "scientific" was introduced to China by the early communist Li Dazhao in 1917 to denote a road leading to a more advanced society, it has had a close association with the idea of "progress". What was seen as "scientific" was more concerned with pragmatism or practical knowledge than with any spiritual pursuit. Many Chinese intellectuals (especially the leftists) thought that social 
progress was accelerated by the "scientific" spirit, and was to be achieved by "going into society", "experiencing the real world" and introducing western technology; while "retrogression" was seen as being caused by the feudal literati's ideas of reclusion (Kong, 2000, p. 90). Some of these intellectuals were influenced by Marxist ideas. It has been commonplace since Marx to speak, in some contexts, of the "progressive" character of capitalism, and within it of urbanism and of social modernization. As Raymond Williams argues, the productive efficiency and the newly liberated forces of the capitalist breakthrough, the simultaneous damnation and idealization of capitalism in its specific forms of urban and industrial development, the unreflecting celebration of man's mastery of nature and his exploitation of natural resources, were all embodied in the word "progress" (Williams, 1973, p. 37). Although for the leftists, capitalism later lost its "progressive" character and was replaced and superseded by socialism, for most of the Chinese intellectuals of the 1920s and 1930s, both capitalism and socialism represented the idea of "progress" when compared with traditional feudalism. In all these embodied meanings of "progress", the active intervention in and transformation of nature and society by human beings is stressed rather than the idea of human beings returning to the natural world as insignificant participants. Similar as in Australian culture, in Chinese culture of this period, in the theme of progress, in terms of the relationship between nature and culture, it is culture which is dominant, symbolized by human activity and a sense of control.

The idea of "actively participating in social life and transforming society" gradually became the prevalent attitude in the 1930s. In traditional Chinese culture, "recluse" was a recurring theme in art and literature. As this art of the recluse was generally escapist, self-cultivating and only for the literati's own amusement, it was unrelated to the desire for a strong nation (in the sense of material prosperity) and "progress"- the popular theme of this new period. The art and literature of this ancient civilization was criticized by some Chinese intellectuals (e.g. Lu Xun) as impeding the advance and progress of the country. As a result, it became the object of attack and vituperation.

Criticism of the "reclusive" spirit was explicit in certain films which promoted the theme of progress. In these films, nature was still represented as a place for reclusion. However, this image was used to criticize those people who had escaped to nature instead of devoting themselves to the national revolution. For example, in A Story on Hua Mountain (Huashan Yanshi) (1934), the Hua Mountain, the ideal site for a recluse, is understood to embody a certain recognizable beauty as a misty paradisal mountain in the traditional painting (Note 3). However, the escape to it of the hero Chen Beifeng as a recluse following the failure of the domestic revolution, is viewed in a negative light, as "pessimistic" and "decadent", and as "cutting himself off from the social struggle" (Figure 5). His image is that of a pessimistic and depressed "coward" rather than that of a traditional "noble" or "honoured" man. The film ends by echoing the call of the revolutionaries through the mouth of the hero, who is shocked and awakened when the city of Shenyang falls into the hands of Japanese in 1931: "I shouldn't live a carefree and leisurely life as a recluse in the mountain. I will safeguard my motherland!" It is significant that in the cultural tradition self-awakening was achieved through leaving society and returning to nature (as exemplified by Tao Yuanming); but during this period it was achieved though leaving nature and returning to society. By condemning the retreat into the mountains, the film in effect condemns the ideology of regarding nature as the sacred shelter and protector for human beings. It deconstructs the traditional praise of human unity with nature.

In this new theme, there was no room for the noble recluse. With the disappearance of the literati class, some intellectuals transmuted their reclusive experience of the joys and sorrows of life from something disengaged to expressions and articulations that were truly of this world. In the reformists' painting, countryside and field were the subject matter, together with images of villages, cultivated fields, roads and houses. Although in traditional painting there were also representations of pavilions, cottages or temples, those images symbolized the communication between man and nature. During this period, however, the cultivated fields and houses were endowed with a more man-made significance, manifesting the human transformation of nature.

Just as Australian filmmakers treated the theme of farmers' labour in their culture, peasants' labour in harsh natural conditions was also a recurring subject in Chinese modern painting, signifying the same kind of transformation (Note 4). One example is Yu Ben (1905-1995)'s Late Returning (1935) (Figure 6) (Note 5). It depicts the toil of man and buffalo and their relationship with the land. In the background is the lingering light of the setting sun, the evening mist, the villages in the distance and the vague hills, all of which was the traditional representation of the pastoral. But in the foreground, there is a stocky clodhopper carrying his plough, pulling a buffalo and walking back home in the open country. The clodhopper, a massive figure forming a sharp contrast to the light natural environment, stands in obvious contrast to the traditional reclusive theme, in which figures are small, at ease and detached. In the painter's eye, the labouring people had the most appeal, for they contributed to the progressive development of society. He claims: "I can only and must paint these stubborn, indocile figures. They live a hard life, but they have a strong and tough character" (Yang, 1989, p. 309). 


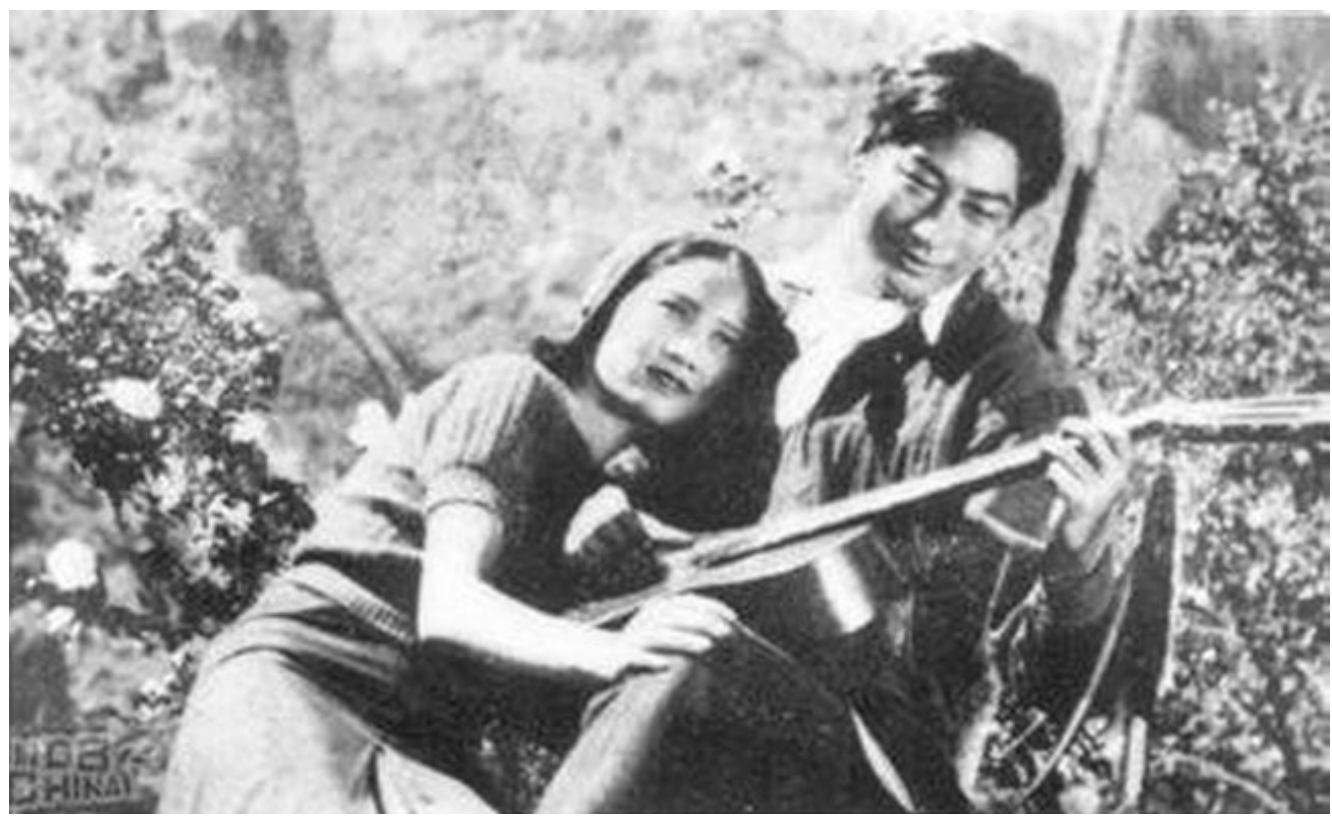

Figure 5. A Story on Hua Mountain (Huashan Yanshi华山艳史) (1934). Chen Beifeng and his girlfriend find refuge in the Hua Mountain



Figure 6. Yu Ben余本 (1905-1995). Late Returning (Wangui晚归) (1935). Oil on canvas. 82 x 94 cm

Echoing Yu Ben's subject of labouring peasants, but with a more radical and impressive strength, Zhao Wangyun (1906-1977) gave full play to this subject. In his painting the figures are labouring figures, and the animals are ploughing animals, as shown in The Ploughmen in the Fields of Longping (c.1933) and The Cattle Harrowing the Soil in Early Spring (c.1933) (Figure 7) (Note 6). He said, "In my painting there will never be those people who 
don't work or labour" (Cheng, 2002, p. 36). As with certain Australian films, such as On Our Selection, Zhao's focus was also on the plight of human beings in their encounters with the harshness of nature. This can be seen in Fatigue (1928), which depicts a peasant in a dry and barren field, leaning on his hoe and gasping painfully (Note 7). Although it is not easy for a painting to construct the theme of progress by narrating the story of an ascent from nothing to a final fulfillment of prosperity (as Australian films did), in Zhao's painting we can still read the message of "progress" because his words which explain the theme of labour reveal his intention: "The feelings outpoured in the process of labour were endless, because labour was a human activity contributing to the creation and development of the country" (Cheng, 2002, pp. 153-154). These words embody an ideology similar to that of the Australian film On Our Selection. Both suggest that nature needs to be controlled and transformed by human labour for the purpose of progress and the development of society.

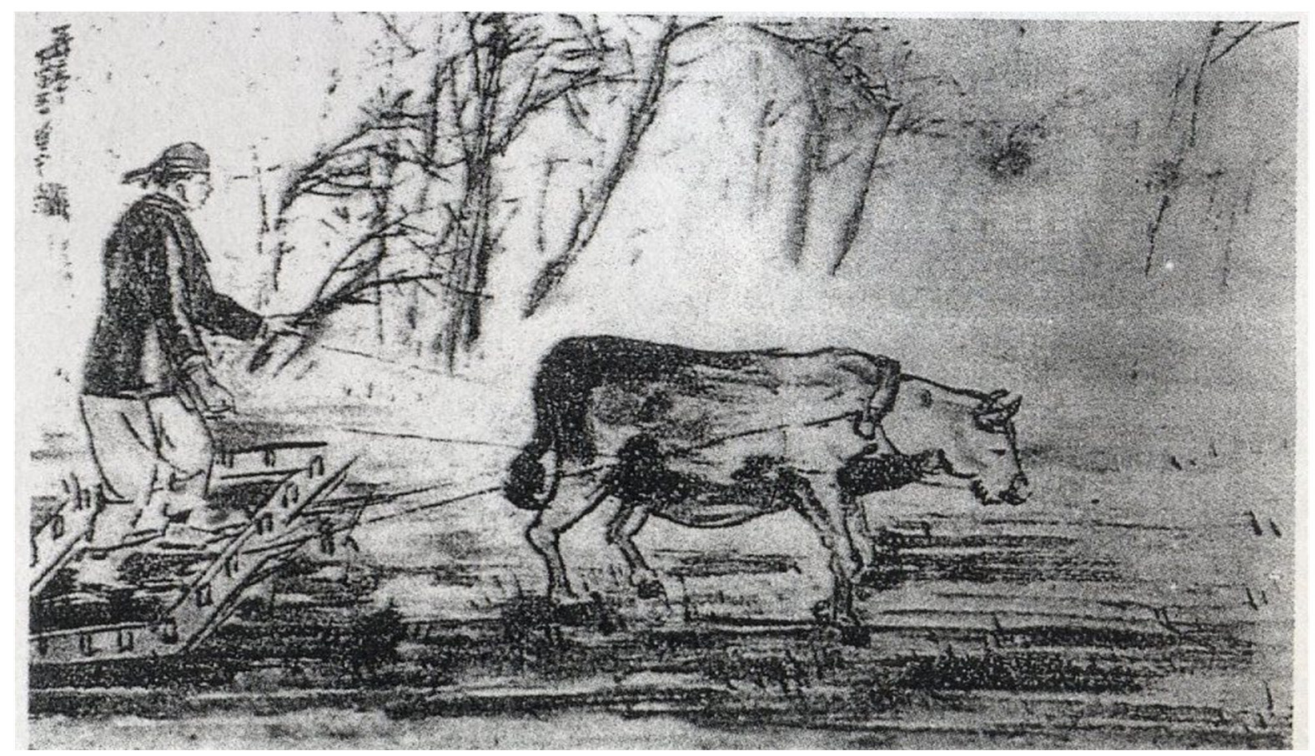

Figure 7. Zhao Wangyun赵望云 (1906-1977). The Cattle Harrowing the Soil in Early Spring (Chunmeng Padi Zhiniu春萌耙地之牛) (c.1933). Ink on paper

\section{Conclusion}

From the above discussion, a conclusion can be drawn that during the 1920s and early 1930s, both Australian and Chinese nationalistic sentiments stimulated the construction of a theme of progress. In this theme, nature was represented as something to be transformed for the purpose of "progress". This theme demonstrated lots of similarities in appearance in both cultures, such as transforming the "waste" or "barren" land, the eulogize of farmers or peasants. In Australian culture, the purpose of constructing human labour improving rural conditions into a pastoral paradise is to pay tribute to the indomitable spirit of the Australian farmer, and to strengthen the belief of civilizing the land by science, technology, settlement and individual self-improvement. In fact, the Australian theme of progress to some extent can be viewed as a contest with the Aborigines for the land - not a battle using the conventional machines of war, but one in which the weapons are the Europeans' way of using the land and their civilizing process. In Chinese culture, besides the implication of transforming "wilderness" into fertile farming land, and scientific and technological development, this theme also has the meaning of "actively participating in social life".

\section{Acknowledgements}

This paper is supported by "Cooperation and Innovation Center in Henan Province for International Dissimilation of Chinese Language".

\section{Notes}

Note 1. The director Ken Hall said of these images in The Squatter's Daughter: "I wanted the wide horizons and beauty of the country to show through on the screen and to suggest in the opening shots the vast size of the wool 
industry... a projection of Australia with which I am glad to have been associated" (See Hall, K. (1977). Directed by Ken. G. Hall: Autobiography of an Australian Film Maker. Melbourne: Lansdowne).

Note 2. These slogans became the guidelines for many Chinese intellectuals and artists.

Note 3. Huashan Yanshi: 华山艳史. The main idea of the film: Chen Beifeng, a student in Peking University, and his girlfriend go to Hua Mountain to spend their holidays. They write poems and play music in the Mountain. Chen's classmate Huang Zhensheng goes to Guangdong, joins the Revolutionary Army and participates in the revolution. Encouraged by Huang, Chen also takes part in the revolution. During the massacre in 1927, Chen becomes pessimistic again and returns to Hua Mountain for three years as a hermit, lonely and depressed. In 1931, when Shenyang falls to the Japanese, his spirit is devastated. After smashing his musical instrument, he joins the army again and is killed in the fighting.

Note 4. Although in an Australian sense "farmer" has a different meaning from "peasant", in this thesis I compare Australian farmers with Chinese peasants from the perspective that both words connote "labouring in nature".

Note 5. Yu Ben: 余本; Late Returning: 晚归.

Note 6. The Ploughmen in the Fields of Longping: 隆平村野代替牛马的耕种人; The Cattle Harrowing the Soil in Early Spring: 春萌耙地之牛.

Note 7. Fatigue:疲劳.

\section{Conflict of interests}

The authors declare that there is no conflict of interests regarding the publication of this paper.

\section{References}

Alomes, S., \& Jones, C. (1991). Australian Nationalism: A Document History. North Ryde: Angus \& Robertson Publishers.

Astbury, L. (1985). City Bushmen: The Heidelberg School and the Rural Mythology. Melbourne: Oxford University Press.

Cheng Z. 程征 (2002). Zhao Wangyun 赵望云. Shijiazhuang: Hebei Jiaoyu Chubanshe.

Hall, K. (1977). Directed by Ken. G. Hall: Autobiography of an Australian Film Maker. Melbourne: Lansdowne.

Hoorn, J. (2007). Australian Pastoral: The Making of a White Landscape. Fremantle: Fremantle Press.

Kong X. M. 孔新苗 (2000). Chinese Painting Aesthetics in the 20 th Century 二十世纪中国绘画美学. Jinan: Shandong Fine Arts Publishing House.

Lu, F. S. (1995). “An Introduction to Twentieth Century Chinese Painting”, in Tradition and Innovation in Twentieth Century Chinese Painting. Hong Kong: Hong Kong Art Gallery.

Mei M. S. 梅墨生 (2005). Studies on Modern Chinese Calligraphy and Painting 现当代中国书画研究. Xi'an: Shaanxi Renmin Meishu Chubanshe.

Radi, H. (1974). In F. K. Crowley (Ed.), A New History of Australia. Melbourne: William Heinemann Australia.

Tulloch, J. (1981). Legends on the Screen: The Narrative Film in Australia 1919-1929. Sydney: Currency Press.

Tulloch, J. (1982). Australian Cinema: Industry, Narrative and Meaning. Sydney: George Allen \& Unwin.

Ward, R. (1966). The Australian Legend (2nd ed.). Melbourne: Oxford University Press.

Williams, R. (1973). The Country and the City. London: Chatto and Windus.

Yang M. S. 杨明生 (1989). Stories of Modern Chinese Painters 中国现代画家传. Zhengzhou: Henan Meishu Chubanshe.

\section{Copyrights}

Copyright for this article is retained by the author(s), with first publication rights granted to the journal.

This is an open-access article distributed under the terms and conditions of the Creative Commons Attribution license (http://creativecommons.org/licenses/by/4.0/). 